\title{
Relationships between plasma lipoproteins and glucose in fasted chickens selected for leanness or fatness by three criteria
}

\author{
D Hermier 1,2,*, MR Salichon 2, CC Whitehead 3
}

\author{
1 INSERM Unité 321, Pavillon B Delessert, Hôpital de la Pitié, \\ 83 boulevard de l'Hôpital, 75651 Paris Cedex; \\ 2 INRA, Station de Recherches Avicoles, Nouzilly, 37380 Monnaie, France; \\ ${ }^{3}$ AFRC, Institute of Animal Physiology and Genetics, Edinburgh Research Station, \\ Roslin, Midlothian EH25 9PS, Scotland
}

(Received 14 January 1991; accepted 26 March 1991)

\begin{abstract}
Summary - In order to identify the mechanisms which underlie fattening in commercial birds, lean and fat broiler chickens have been selected according to 3 different criteria: abdominal fat content, plasma glucose level and plasma concentration of very-low-density lipoproteins (VLDL), the latter being the main substrate from which bird adipose tissues accumulate triglycerides. Chickens selected for high abdominal fat content displayed a higher level of VLDL and a lower level of glucose than their lean counterparts. Conversely, selection for high plasma VLDL or low plasma glucose resulted in 2 fat lines of chickens. The differences in intermediate- and low-density lipoproteins reflected a different balance in synthesis and catabolism of VLDL among the lines, whereas there was no difference in high-density lipoproteins. These data clearly demonstrate the relationship between lipid and carbohydrate metabolism and their role in the susceptibility to fattening. They suggest a greater use of carbohydrate for hepatic lipogenesis in fat chickens, resulting in a higher synthesis and secretion of VLDL and of their subsequent accumulation of triglycerides in the adipose tissue.
\end{abstract}

lipoprotein / glycaemia / fattening / chicken

Résumé - Relations entre les lipoprotéines et le glucose plasmatiques chez des poulets à Jeun sélectionnés par trols critères sur leur maigreur ou leur adiposité. Afin d'identifier les mécanismes de l'engraissement chez les oiseaux d'élevage, la sélection de poulets de chair maigres ou gras a été réalisée selon trois critères différents : quantité de tissu adipeux abdominal, glycémie ou taux plasmatique de VLDL (very low density lipoproteins : lipoprotéines de très basse densité), ces VLDL représentant le principal substrat à partir duquel le tissu adipeux des oiseaux accumule les triglycérides. Les poulets sélectionnés pour leur pourcentage élevé de tissu adipeux abdominal ont des VLDL plus abondantes et une glycémie plus faible que leurs congénères maigres. Inversement, la sélection pour un taux élevé de VLDL ou une faible glycémie a permis d'obtenir deux lignées de poulets gras. Les différences portant sur les lipoproteines de densité faible ou intermédiaire reflètent l'état d'équilibre entre la synthèse et le catabolisme des VLDL dans les diverses lignées, tandis qu'aucune différence n'apparaît en ce qui concerne les lipoprotéines de haute densi-

* Correspondence and reprints 
té. Ces données montrent bien les relations entre le métabolisme des lipides et celui des glucides, ainsi que leur rôle dans la sensibilité à l'engraissement. Elles suggèrent que l'utilisation des glucides à des fins de lipogenèse hépatique est plus importante chez les poulets gras, entrainant l'augmentation de la synthèse et de la sécrétion des VLDL, puis l'accumulation des triglycérides par le tissu adipeux.

Ilpoprotéines / glycémie / engraissement / poulet

\section{INTRODUCTION}

The interest of consumers in lean meat has resulted in a number of studies on the factors which determine fattening in broiler chickens. Several selection studies have demonstrated a genetic component in broiler fatness. The first study involved divergent selection on the basis of abdominal fatness of siblings and resulted in lean (LL) and fat (FL) lines of broiler chickens (Leclercq et al, 1980). It was observed that the FL birds had lower fasting plasma glucose and higher VLDL concentrations than the LL chickens (Touchburn et al, 1981; Hermier et al, 1984) and these metabolic criteria also have been used as a basis for selection. Whitehead and Griffin (1984) described a procedure based on selection for low or high plasma very low density lipoprotein (VLDL) concentration in fed birds that resulted in lean (L-VLDL) and fat (H-VLDL) lines of broilers. Selection on the basis of plasma glucose resulted in a low plasma glucose (L-G) line that was fatter than the high glucose $(\mathrm{H}-\mathrm{G})$ line (Leclercq et al, 1987).

The metabolic basis for fatness in these lines selected according to 3 separate criteria is of interest. The ability to synthesize fatty acids is quite limited in avian adipose tissue (Leveille et al, 1975); moreover, commercial chickens are often fed diets which contain relatively low levels of lipids. Consequently, hepatic VLDL are the major plasma substrate from which adipocytes accumulate triglyceride. Positive relation- ships between plasma VLDL and body fatness in the various selected lines suggests that fattening largely depends on the availability of the lipid substrate for adipocyte uptake. Indeed, elevated plasma VLDL concentrations in fat chickens do not result from impaired catabolism of these particles (Hermier et al, 1989) but rather from an increase in their synthesis and secretion by the liver (Legrand et al, 1987; Saadoun and Leclercq, 1987; Griffin et al, 1991). It has also been postulated, on the basis of observations on LL and FL birds, that glucose-insulin imbalance may influence lipid synthesis and accumulation (Touchburn et al, 1981; Simon and Leclercq, 1982).

The object of the present study was to compare some characteristics of the lines selected by the 3 methods to help in determining to what extent similar mechanisms might be responsible for the differences in body fatness in the 3 pairs of lines. Measurements were made of glucose levels and lipoprotein profiles in the plasma of fasted birds.

\section{MATERIALS AND METHODS}

\section{Animals}

Male chickens differing in abdominal fat content ( $\mathrm{LL}$ and $\mathrm{FL}, \mathrm{F}_{7}$ generation) or plasma glucose concentration ( $H-G$ and $L-G, F_{4}$ generation), were provided by the Poultry Research Station (INRA, Nouzilly, France), whereas birds selected on plasma VLDL levels (H-VLDL and L- 
VLDL, $F_{5}$ generation) were bred at the Edinburgh Research Station (AFRC, Roslin, Scotland). They were fed growing diets containing $19-21 \%$ protein, $4.4 \%$ (French diet) or $6.5 \%$ (Scottish diet) lipid and 12.6-13.8 MJ metabolisable energy/kg.

At 7 wk of age, after an overnight fast, the animals were weighed, blood samples were collected using EDTA as anticoagulant and plasma was separated by centrifugation at $500 \mathrm{~g}$ and $4^{\circ} \mathrm{C}$ for 15 min. H-VLDL and L-VLDL chickens were killed immediately after blood sampling in order to measure abdominal fat content. LL, FL, H-G and L-G chickens were reared to 9 wk for commercial slaughtering; for this reason, direct measurement of abdominal adipose tissue was not possible, but it was assumed to be similar to that of the respective general populations of the same line, generation and age (Rideau et al, 1986; Leclercq et al, 1987).

\section{Lipoprotein isolation}

Lipoproteins were isolated from plasma on the basis of their hydrated density in a single step according to the ultracentrifugal gradient procedure described by Chapman et al (1981) and modified by Hermier et al (1985). Ultracentrifugation was performed in a Beckman L8-55 ultracentrifuge using a Beckman SW41 rotor at $40,000 \mathrm{rpm}\left(56 \times 10^{7} \mathrm{~g} \cdot \mathrm{min}\right)$ for $48 \mathrm{~h}$ at $15^{\circ} \mathrm{C}$. The fractionation procedure took into account the alternance of pigmented and non-pigmented bands corresponding to the successive lipoprotein classes, as described previously in man (Chapman et al, 1981) and chicken (Hermier et al, 1985). Four lipoprotein classes were thus separated from the top to the bottom of the gradient, with the following respective densities: VLDL $(d<1.013 \mathrm{~g} / \mathrm{ml})$, intermediate density lipoproteins (IDL, $d 1.013-1.020 \mathrm{~g} / \mathrm{ml}$ ), low density lipoproteins (LDL, d 1.020-1.040 g/ml), and high density lipoproteins (HDL, d 1.065-1.165 g/ $\mathrm{ml})$.

Lipoproteins were dialysed in Spectrapor tubing (Spectrum Medical Industries, Los Angeles, $\mathrm{CA}$; mol wt cut-off 12000 ) for $48 \mathrm{~h}$ at $4{ }^{\circ} \mathrm{C}$ against a solution containing $0.05 \mathrm{M} \mathrm{NaCl}$, $0.005 \mathrm{M} \mathrm{NH}_{4} \mathrm{HCO}_{3}, 0.04 \%$ EDTA and $0.01 \%$ sodium azide at $\mathrm{pH}$ 7.4.

\section{Chemical analyses}

The following components were quantified in each lipoprotein fraction and in whole plasma as follows : proteins by the method of Lowry et al (1951) using bovine serum albumin (Sigma, Saint-Louis, MO, USA) as a standard; triglyceride, free cholesterol, total cholesterol and phospholipids by enzymatic methods (Richmond, 1973; Takayama et al, 1977; Fossati and Prencipe, 1982), using the kits provided by BioMérieux (Charbonnière-les-Bains, France). The amount of cholesteryl esters was calculated using the formula:

cholesteryl ester $=$

(total cholesterol-free cholesterol) $\times 1.67$

In this calculation, it was assumed that the factor for the ratio of the average molecular weight of chicken plasma cholesteryl esters to that of the molecular weight of free cholesterol (ie 1.67), was the same in man and the chicken. Glucose concentration was measured by the glucose oxidase method using a Beckman glucometer (Kadish et al, 1968).

\section{Statistical analyses}

Results were expressed as mean $\pm S D$. Significance of difference was tested using Student's $t$ test.

\section{RESULTS}

At 7 wk of age, chickens from the $L L$ and FL lines were considerably lighter than the other groups (table I). However, for each selection criterion, the difference between the 2 lines was never significant. Conversely, in all cases, the proportion of abdominal fat content did respond to the selection. This was the case in $\mathrm{LL}$ and $\mathrm{FL}$ chickens, in which the amount of abdominal adipose tissue was used as the parameter for direct selection, but is was also 


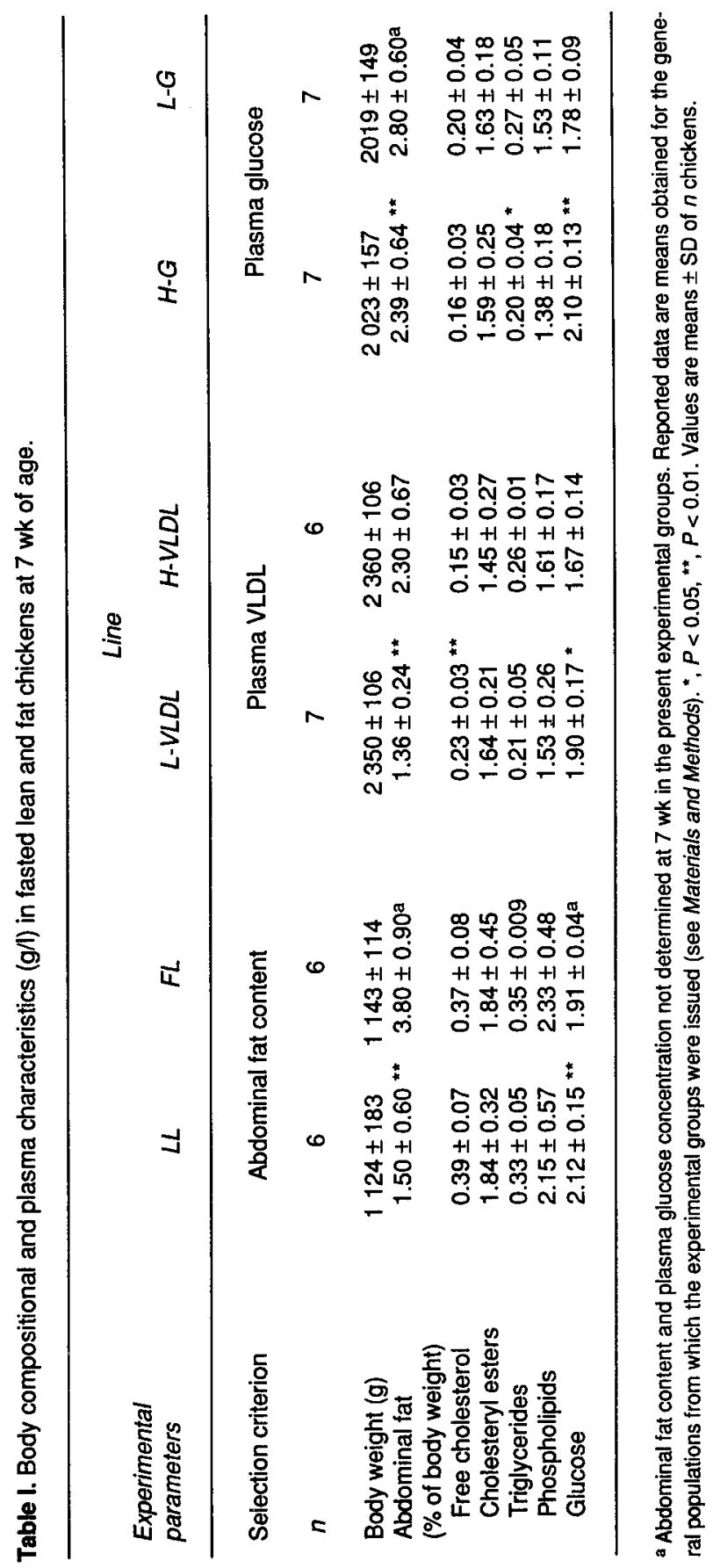


confirmed in the other lines: chickens exhibiting high plasma VLDL (H-VLDL) or low plasma glucose (L-G) were always fatter than their respective counterparts. However, direct selection on abdominal fat content was the most effective, whereas the difference between $H-G$ and $L-G$ chickens was smallest, but still significant.

Lines selected on either glycemia or plasma VLDL displayed similar concentrations of all plasma lipids. However, free cholesterol level was significantly higher in L-VLDL chickens than in the fat birds, whereas the concentration of triglycerides was lower in $\mathrm{H}-\mathrm{G}$ chickens than in their $\mathrm{L}-$ $\mathrm{G}$ counterparts. $\mathrm{LL}$ and $\mathrm{FL}$ chickens differed from the other lines in that their plasma lipid levels were systematically higher.

The appearances of density gradients after ultracentrifugation were very similar in all the birds studied. Since the animals were fasted, VLDL concentrations were very low (table II). Within each population, chickens with the higher abdominal fat content, ie FL, H-VLDL, and L-G chickens, exhibited the higher levels of VLDL, although the difference was not significant between $\mathrm{H}-\mathrm{G}$ and $\mathrm{L}-\mathrm{G}$ lines. In all cases, VLDL composition was typical of immature chickens, with a rather elevated proportion of protein (20-27\%). Triglyceride content varied considerably $(30-50 \%$ of the particle weight), but remained within the physiological values normally found in immature chickens. It is noteworthy that VLDL in the $\mathrm{H}-\mathrm{G}$ and $\mathrm{L}-\mathrm{G}$ chickens were richer in triglycerides than those in the other lines. Phospholipids and cholesteryl esters were found in comparable amounts, while free cholesterol was a minor component.

Quantitative and qualitative variation of IDL parallelled that of VLDL (table III). Indeed plasma concentration of IDL was higher in fat chickens (though the difference between FL and LL was not significant), whereas particles isolated from $\mathrm{H}-\mathrm{G}$ and L-G chickens contained more triglyceride and less cholesteryl esters than those of the other lines. Surprisingly, plasma LDL levels were significantly lower in fat birds of both the FL and the H-VLDL lines, whereas it was higher in fat birds of the L$\mathrm{G}$ line (table IV). On the other hand, the chemical composition of the LDL particles was quite similar in the 6 lines. HDL (table V) represented, as normal in avian species, the major lipoprotein class (3.4-4.6 g/ I). Protein was their major component (nearly $50 \%$ in weight), whereas triglyceride content was low. Nevertheless, plasma HDL concentrations were always higher in fat lines of chickens although neither these differences in concentration, nor those in chemical composition, attained statistical significance.

\section{DISCUSSION}

This study of chickens selected by 3 very different criteria demonstrated some consistent metabolic difference between lean and fat birds. More precisely, fattening is associated with high plasma VLDL level and low glucose level. Whilst it is likely that several mechanisms can influence body fatness, and the balance between these mechanisms may differ in the lines selected by different methods, the results nevertheless suggest that common relationships between lipid and carbohydrate metabolism exist in these lines.

There is a strong relationship between fattening and VLDL levels. Elevated plasma VLDL provide a greater amount of triglyceride substrate for adipocyte development in the 3 pairs of selected lines. Of course, plasma VLDL concentration is not uniformly related to fatness over all lines because there are also genetic differences in VLDL catabolism. Thus, the lipoprotein lipase activity in the abdominal adipose tis- 


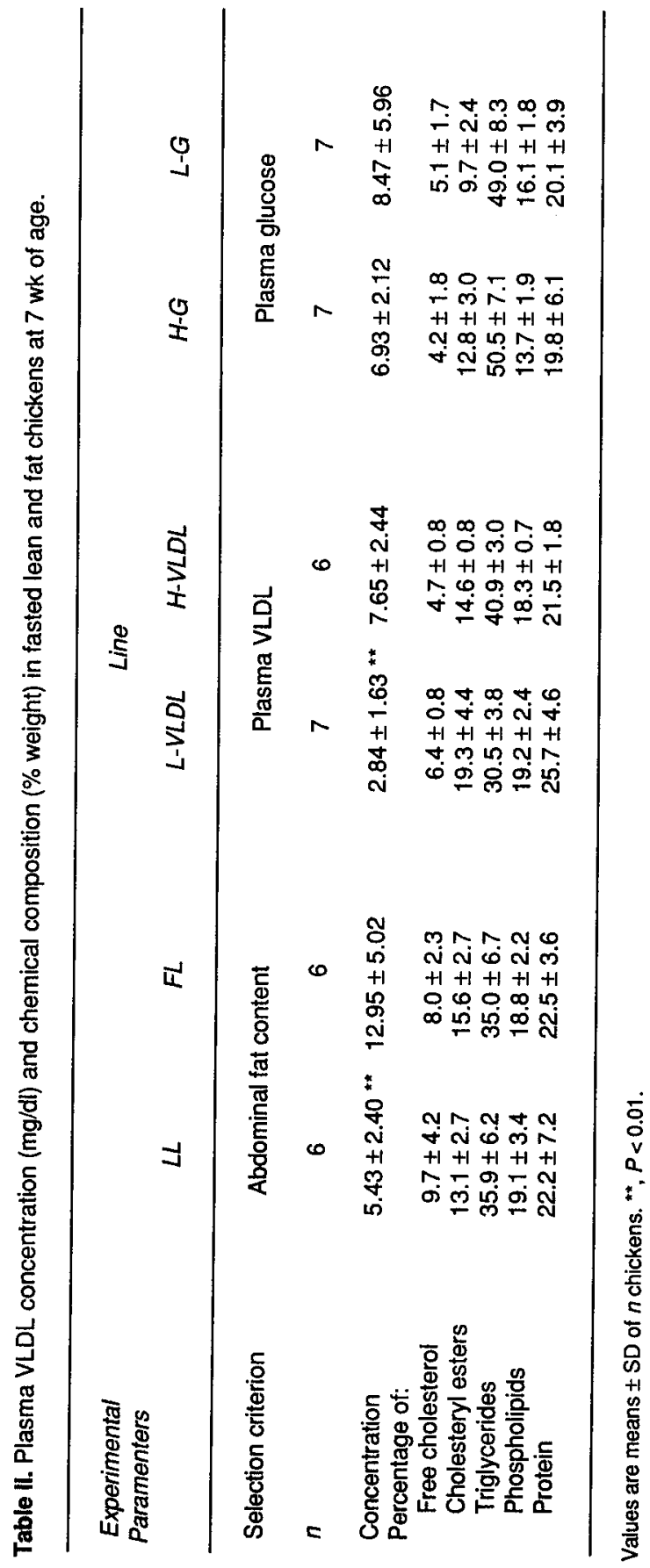




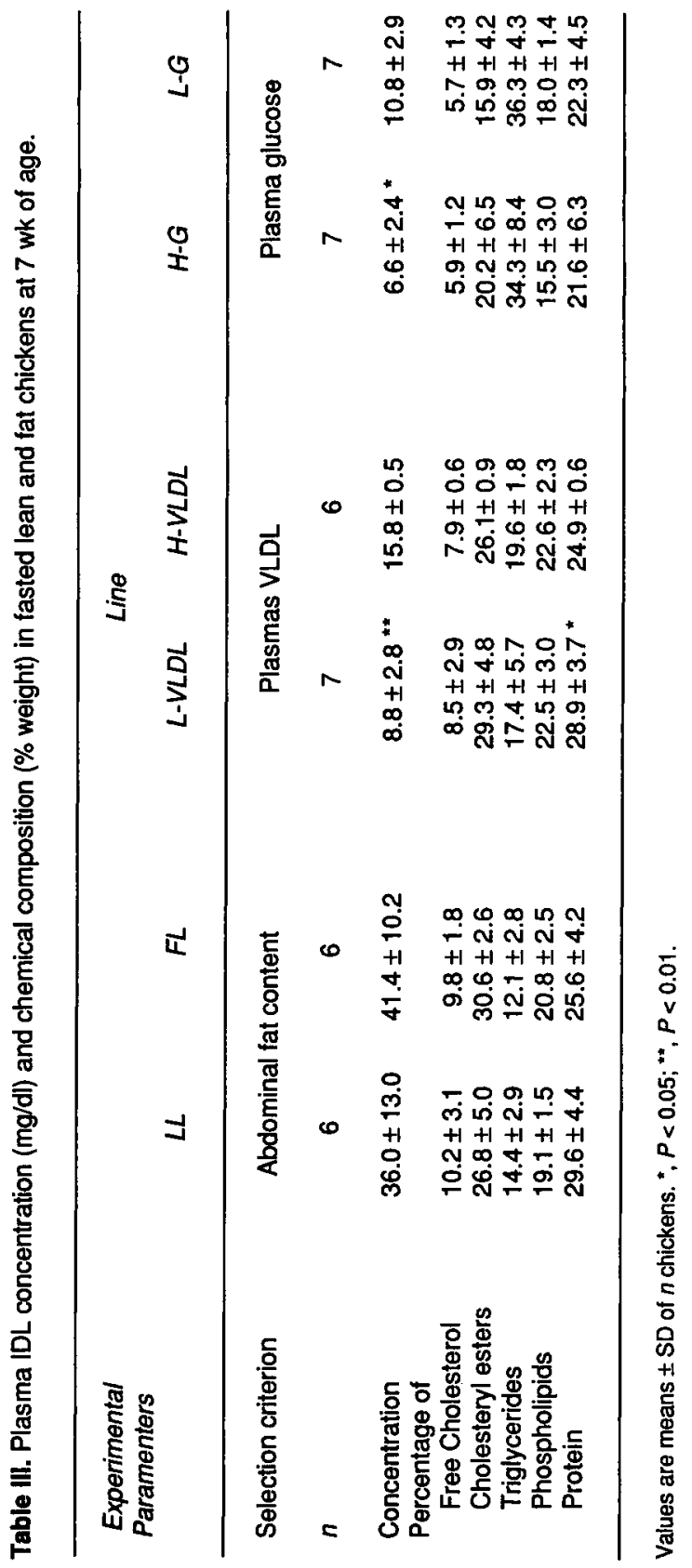




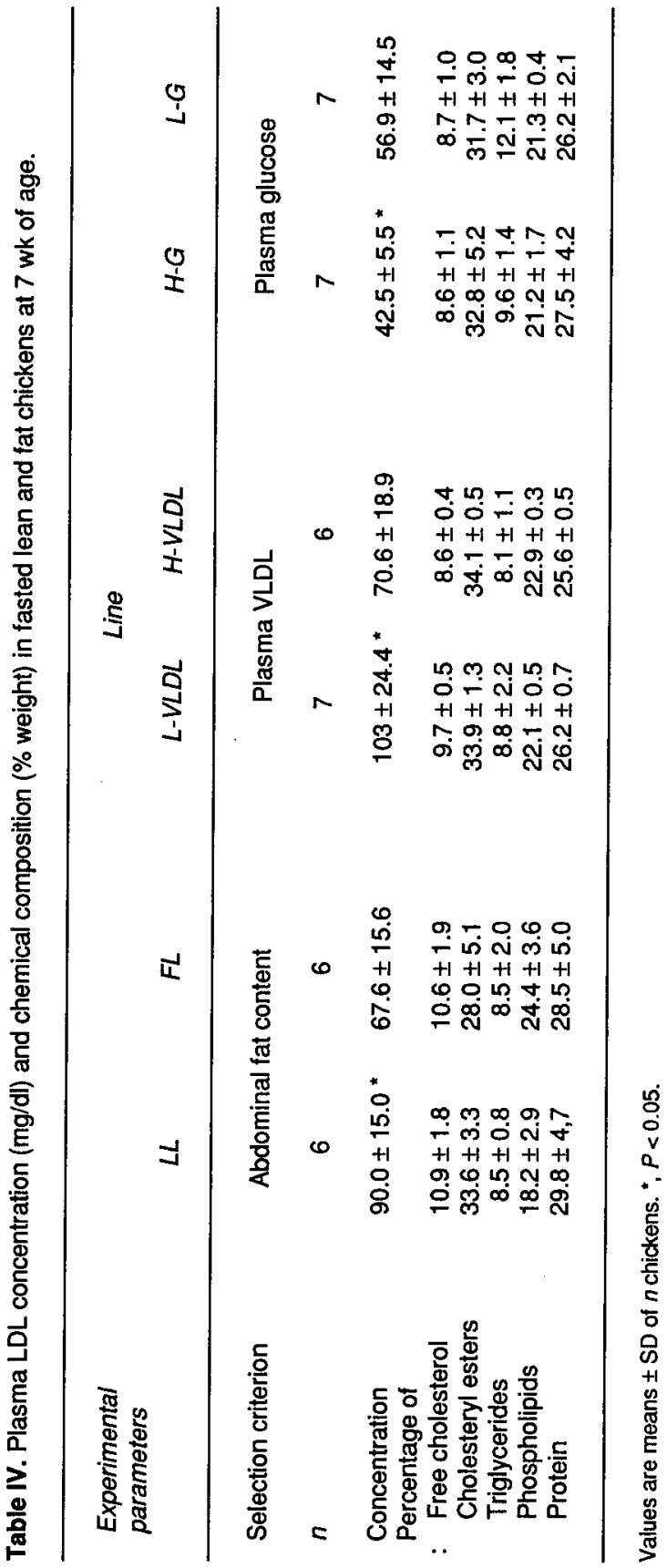




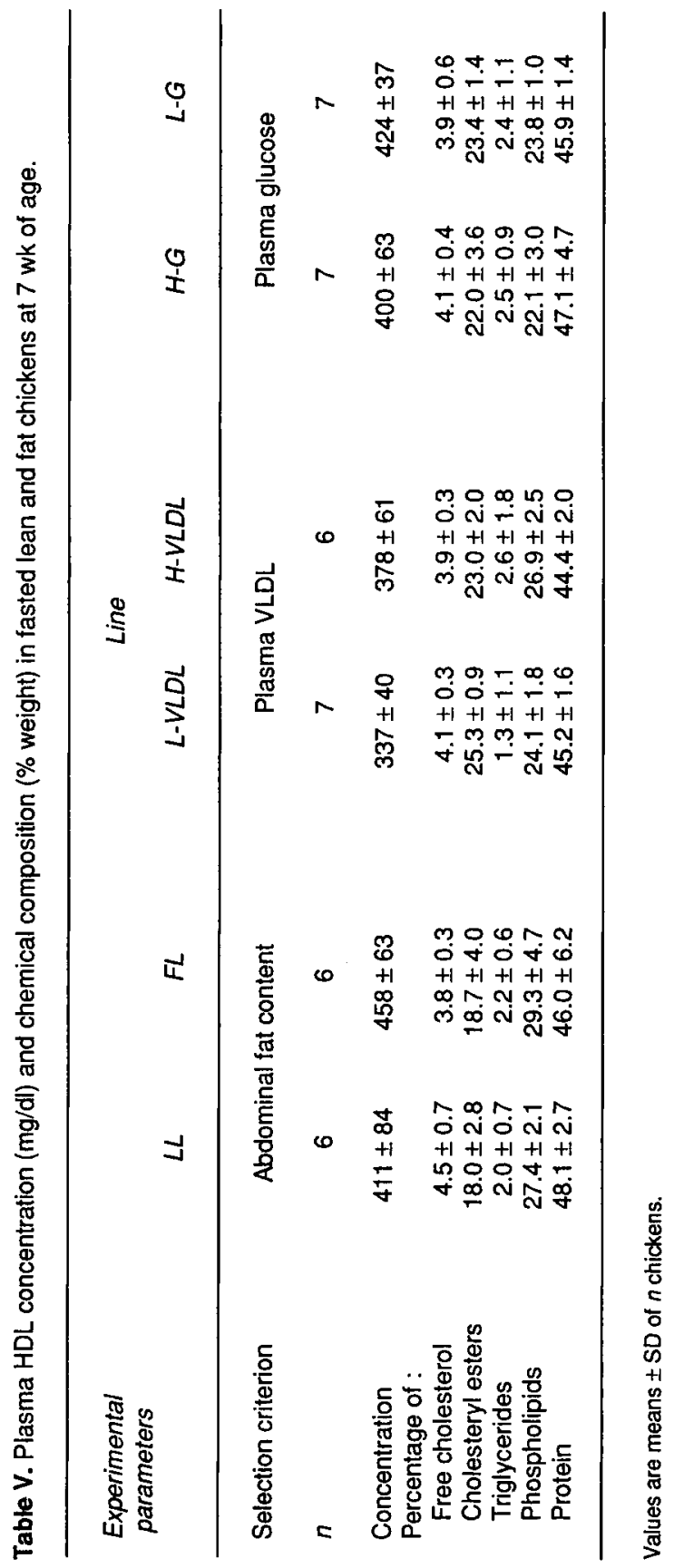


sue has been shown to be higher in FL chicken than in the LL birds (Hermier et al, 1989), whereas no difference was found between H-VLDL and L-VLDL chickens (Griffin et al, 1989). These differences in LPL may explain why the FL and LL lines show a greater divergence of abdominal fatness relative to VLDL that the H-VLDL and L-VLDL lines. No data is available concerning $H-G$ and $L-G$ chickens. The balance between synthesis and catabolism may thus differ between lines and may also explain the variations of IDL and LDL. However, these differences seem to affect only triglyceride-rich lipoproteins. In all lines, the concentration and chemical composition of HDL, which are the second class of lipoproteins synthesized and secreted by the liver, were not influenced by the selection process.

Two mechanisms may contribute to the lower fasting plasma glucose levels seen in the 3 fatter lines. Firstly, increased VLDL secretion is thought to be associated with greater hepatic lipogenesis in the fatter lines (Bannister et al, 1984; Legrand et al, 1987; Saadoun and Leclercq, 1987). Lower levels of glucose, a substrate for lipogenesis, may therefore result from this enhanced lipogenesis. It has been hypothesized that FL chickens express a greater sensivity to insulin, which may account for both hypoglycemia and increased hepatic lipogenesis (Saadoun et al, 1988; Simon, 1988). The use of different substrates for energy generation may also be a factor. Griffin et al (1989) observed elevated plasma $\beta$-hydroxybutyrate levels in the L-VLDL line and suggested that this resulted from a preferential direction of fatty acids towards oxidation. A consequence of this conclusion would be that fat birds might generate proportionately more energy from carbohydrate, and show lower glucose levels in consequence.

\section{CONCLUSION}

In conclusion, it is apparent that the susceptibility to fattening in the chicken is associated with lower levels of plasma glucose and higher levels of plasma VLDL, independent of the selection criterion. These findings are in good agreement with the statement that, in fat chickens, there is a change in the balance of energy metabolism towards an increase of triglyceride synthesis from the carbohydrate component of the diet. The hypotheses that the lower glucose levels in fat birds reflect a greater sensitivity to insulin and may also indicate preferential oxidation of carbohydrate need to be tested more widely in lean and fat chickens.

\section{ACKNOWLEDGMENTS}

$B$ Leclercq and $J$ Simon kindly provided chickens from the $L L, F L, H-G$ and $L-G$ lines (INRA, Poultry Research Station, France). We gratefully acknowledge the technical assistance of $\mathrm{J}$ Armstrong, B Chevalier, M Derouet and G Guy. $\checkmark$ Soulier kindly prepared the typescript.

\section{REFERENCES}

Bannister DW, Lee A, Whitehead CC, Griffin HD (1984) Lipogenic enzyme activity and fructose 2,6-biphosphate concentration in livers of two lines of domestic fowl (Gallus domesticus) selected for different body fat content. Int J Biochem 16, 1301-1305

Chapman MJ, Goldstein S, Lagrange D, Laplaud PM (1981) A density gradient ultracentrifugal procedure for the isolation of the major lipoprotein classes from human serum. $J$ Lipid Res 22, 339-358

Fossati $P$, Prencipe L (1982) Serum triglycerides determined colorimetrically with an enzyme that produces hydrogen peroxyde. Clin Chem 28, 2077-2080 
Griffin HD, Acamovic F, Guo K, Peddie J (1989) Plasma lipoprotein metabolism in lean and in fat chickens produced by divergent selection for plasma very low density lipoprotein concentration. J Lipid Res 20, 1243-1250

Griffin HD, Windsor D, Whitehead CC (1991) Changes in lipoprotein metabolism and body composition in chickens in response to divergent selection for plasma very low density lipoprotein concentration. Br Poult Sci 32, 195-201

Hermier D, Chapman MJ, Leclercq B (1984) Plasma lipoprotein profile in fasted and refed chickens of two strains selected for high or low adiposity. J Nutr 114, 1112-1121

Hermier D, Forgez P, Chapman MJ (1985) A density gradient study of the lipoprotein and apolipoprotein distribution in the chicken, Gallus domesticus. Biochim Biophys Acta 836, $105-118$

Hermier D, Quignard-Boulangé A, Dugail I, Guy G, Salichon MR, Brigant L, Ardouin B, Leclercq $B$ (1989) Evidence of enhanced storage capacity in adipose tissue of genetically lean and fat chickens. J Nutr 119, 1369-1379

Kadish AH, Little RL, Sternberg JC (1968) A new rapid method for the determination of glucose by measurement of rate of oxygen consumption. Clin Chem 14, 116-131

Leclercq B, Boyer JP, Blum (1980) Selecting broilers for low or high abdominal fat: initial observations. Br Poult Sci 21, 107-113

Leclercq B, Simon J, Ricard F (1987) Genetic selection of chikens for high of low plasma glucose concentration. Br Poult Sci 28, 557 565

Legrand P, Mallard J, Bernard-Griffiths MA, Douaire M, Russeil P, Lemarchal P (1987) Lipid biosynthesis and deposition in genetically lean and fat chickens. Comparative in vivo studies with ${ }^{14} \mathrm{C}$ acetate. Comp Biochem Physiol 86B, 791-796

Leveille GA, Romsos DR, Yeh YY, O'Hea EK (1975) Lipid biosynthesis in the chick. A consideration of site of synthesis, influence of diet and possible regulatory mechanisms. Poult Sci 54, 1075-1093
Lowry OJ, Rosebrough NJ, Farr AL, Randall RJ (1951) Protein measurement with the Folin phenol reagent. J Biol Chem 193, 265-275

Richmond W (1973) Preparation and properties of a cholesterol oxydase from Nocardia $\mathrm{sp}$ and its application to the enzymatic assay of total cholesterol in serum. Clin Chem 79, 9398

Rideau N, Simon J, Leclercq B (1986) Further characterization of insulin secretion from the perfused duodenum-pancreas of chicken: a comparison of insulin release in chickens selected for high or low abdominal fat content. Endocrinology 119, 2635-2640

Saadoun A, Leclercq B (1987) In vivo lipogenesis of genetically lean and fat chickens: effects of nutritional state and dietary fat. $J$ Nutr $117,428-435$

Saadoun A, Simon J, Williams J, Leclercq B (1988) Levels of insulin, corticosterone, $T_{3}$, $\mathrm{T}_{4}$ and insulin sensitivity in fat and lean chickens. Diabet Metab 14, 97-103

Simon $J(1988)$ Insulin in birds: metabolic effects and possible implications in genetically fat and lean chickens. In: Leanness in Domestic Birds (Leclercq B, Whitehead CC, eds) Butterworth, London, 253-268

Simon J, Leclercq B (1982) Longitudinal study of adiposity in chickens selected for high or low abdominal fat content: futher evidence of a glucose-insulin imbalance in the fat line. J Nutr 112, 1961-1973

Takayama M, Itoh S, Nagasaki T, Tanimizu I (1977) A new enzymatic method for determination of serum choline-containing phospholipids. Clin Chim Acta 19, 1350-1355

Touchburn SP, Simon J, Leclercq B (1981) Evidence of a glucose-insulin imbalance and effect of dietary protein and energy level in chickens selected for high abdominal fat content. J Nutr 111, 325-335

Whitehead CC, Griffin HD (1984) Development of divergent lines of lean and fat chickens using plasma very low density lipoprotein concentration as selection criterion: the first three generations. Br Poult Sci 25, 573-582 